\title{
Macrobotanical remains and shell-midden formation processes, are they related? The case of Poças de São Bento (Portugal)
}

\author{
I. López-Dóriga ${ }^{1}$ - M. Diniz ${ }^{2}$ - P. Arias ${ }^{3}$
}

Received: 31 August 2016 / Accepted: 20 October 2016

(C) Springer-Verlag Berlin Heidelberg 2016

\begin{abstract}
The analysis of plant macroremains from Poças de São Bento, a shell-midden in the Sado Valley (Portugal), has provided interesting insights into the shell-midden formation processes and the presence of resources which are often "invisible" in this kind of sites. Preservation and representation issues are discussed in a bidirectional way. Potential complementary explanations for the presence of such plant remains in hunter-gatherer open-air sites are offered. The understanding of plant exploitation patterns by these last huntergatherers in Portugal is crucial for the comprehension of the multifaceted phenomena of Neolithisations, in this case, characterised by a long availability phase and ultimate adoption of domesticates.
\end{abstract}

Keywords Mesolithic · Neolithisation · Archaeobotany · Hunter-gatherers · Taphonomy

I. López-Dóriga

i.lopezdoriga@wessexarch.co.uk

M. Diniz

m.diniz@fl.ul.pt

P. Arias

ariasp@unican.es

1 Wessex Archaeology Portway House Old Sarum Park, Salisbury SP4 $6 \mathrm{~EB}, \mathrm{UK}$

2 Centro de Arqueologia (UNIARQ), Departamento de História, Faculdade de Letras, Universidade de Lisboa, Alameda da Universidade, 1600-214 Lisbon, Portugal

3 Instituto Internacional de Investigaciones Prehistóricas de Cantabria, Edificio Interfacultativo, Avda. de los Castros, 52,

39005 Santander, Spain

\section{Introduction}

In the European Atlantic façade, the introduction of domesticated species is an apparently late, heterogeneous and complex matter, partly due to the persistence of many foraging societies well after the introduction of agricultural technology into neighbouring regions (Arias 2007). In the Atlantic coast of the Iberian Peninsula, in Portugal in South-Western Europe, the phenomenon is further complicated by the absence of coherent multidisciplinary data (Cruz Berrocal 2012). Moreover, because of the limitations imposed by the taphonomy of the contexts and the uncertainties concerning the dated samples, a great part of the available radiocarbon chronology should be regarded with caution (Carvalho 2010). According to the current evidence, the most likely explanation for the introduction of domesticated species is the arrival by sea (e.g. Martins et al. 2015; Zilhão 2011). However, the acceptance of this premise of the model does not necessarily confirm the colonisation of inhabited areas (probably not really uninhabited after all, see Berger and Guilaine 2009) by Neolithic immigrants nor exclude the adoption of domesticated species by the Mesolithic populations, either done readily or gradually (e.g. Dean, Valente and Carvalho 2012; Jackes, Lubell and Meiklejohn 1997; Jorge 2000). Indeed, the latest genetical evidence seems to argue in favour of an integration of a small group of people in the Neolithic with previously existing populations of a Palaeolithic/Mesolithic origin (Santos et al. 2014 against Chandler, Sykes and Zilhão 2005 and Lalueza Fox 1996). Single explanatory and linear models are being criticised, and regional mosaics of distinct processes are being identified (Cruz Berrocal 2012). The earliest littoral Neolithic sites in Portugal with domesticated species occur in the sixth millennium cal BCE (Carvalho 2010; López-Dóriga and Simões 2015), contemporary to the Late Mesolithic occupation of estuarine regions with shell-midden sites. Therefore, it is a 
necessary step to characterise these latest hunter-gatherer societies in the area in order to be able to get a further understanding of the events occurring in the sixth millennium cal BCE. The study of shell-middens in Europe to better understand the Mesolithic-Neolithic transition is a well-trodden topic of research (Álvarez et al. 2011). Although shell-midden research has a long tradition and a methodological renovation is being brought forwards (Álvarez et al. 2011; Balbo et al. 2011), plant remains play a minor role or are rarely even mentioned. This is a relatively common weakness in studies about hunter-gatherer sites in general, despite the major role plant resources must have played (Antolín, Berihuete and López 2016). It was the purpose of this research to bring plant macroremains, often unsearched or/and unfound, to the arena, as they have scarcely been permitted to play any role in this discussion before.

During the Mesolithic, human population in Central and South Portugal seems to move from the littorals and concentrate semisedentarily around big river estuaries (namely the Tagus-Muge, Sado and Mira, see Fig. 1) and the upper southern coast (littoral Alentejo), creating characteristic shellmiddens which were deposited during a time lapse of about a millennium (Araújo 2009). Around 50 Mesolithic shell-middens, most of them in open-air sites, are known and many of them have been already excavated (Gutiérrez-Zugasti et al. 2011). Unfortunately, the panorama is blurred by the fact that a great amount of research was carried out in the earlier twentieth century, when records were not kept in ideal conditions. These sites are characterised by intense shell-food processing (possibly overvalued; Balbo et al. 2011) accompanied of other domestic and funerary activities which suggest certain degree of sedentism (Araújo 2015). The high intersite variability (resources exploited, size of the middens, presence of features, such as postholes or hearths) and the homogeneity of the material culture and funerary rites are usually interpreted in two divergent ways (Diniz and Arias 2012): as a single settlement system per estuary, with residential sites, seasonally but regularly occupied in alternating seasons (Arnaud 1985; GutiérrezZugasti et al. 2011) or with different populations inhabiting different sites (Guiry, Hillier and Richards 2015; Umbelino et al. 2007). Dogs were the only domesticated animals, according to the abundant faunal studies carried out; however, no actual data existed regarding the presence or absence of plant domesicates. It has been a common assumption in Portuguese archaeology that charred plant remains are not preserved and archaeobotany is generally underdeveloped (Tereso et al. 2015). As a consequence, only a twice (one in the Sado and one in the Tagus-Muge area) sampling for plant remains has been carried out in shell-middens and results were negative (Larsson, pers. comm.) or remain unpublished (Wollstonecroft et al. 2006). Thus, the only evidence regarding the consumption of plant resources (other than wood, Monteiro 2013) was indirect and came from isotopic values in bones (e.g. Guiry, Hillier and Richards 2015; Umbelino et al. 2007) which usually undervalue the importance of plant foods (Fraser et al. 2013). New research with innovative methodologies has been carried out recently in the area to overcome this shortcoming and bring plant resources into the discussion.

\section{Materials and methods}

\section{The site}

The site of Poças de São Bento (Fig. 1) was first excavated in the Late 1950s by Manuel Heleno (Machado 1964), the director of the National Museum of Archaeology at Lisbon. Later research included a test pit in 1986 and a partial excavation between 1987 and 1988, by a team lead by José Morais Arnaud, from the Portuguese Institute of Archaeology, and Lars Larsson, from Lund University in Sweden (Arnaud 1985; Arnaud 1989; Arnaud 1990; Arnaud and Larsson 1994; Arnaud 1993; Arnaud 2000; Larsson 1996; Larsson 2010). More recently, research digs have been carried out since 2010 within the framework of the Spanish-Portuguese project Sado-Meso, under the direction of Pablo Arias and Mariana Diniz from the universities of Cantabria (Spain) and Lisbon (Diniz and Arias 2012; Arias et al. 2016; Arias et al. 2015).

Poças de São Bento, with around $4000-3500 \mathrm{~m}^{2}$, is the second largest shell-midden in the Sado valley shell-midden system (Arnaud 1989). It belongs to a cluster of 12 shellmiddens, and, like the others, its height is not conspicuous, being at most $1.5 \mathrm{~m}$. The juxtaposition of small depositional mounds, instead of the massive accumulation of detritus in the same mound (as occurs in the Muge-Tagus shell-middens) or the predominance of a type of shell, peppery furrow shell (Scrobicularia plana), over more bulky ones, such as common cockle (Cerastoderma edule), might be the reason(s) for this relatively small height (Arias, pers. comm.). Animal remains, mostly shell (Álvarez-Fernández et al. 2012), crustacean and marine fish remains (Gabriel, Diniz and Arias 2013), and also mammal bones were recovered. A small proportion of the bones were found to have been transformed into tools, and several perforated shells and fish vertebra were also identified. Lithic raw material was primarily local (Pimentel et al. 2015) and was transformed in situ into tools, including microliths (Araújo, Arias and Diniz 2015). Fire-cracked rocks, small concentrations of fire-altered shells and wood charcoal fragments served to identify several small hearths, and several possible postholes were tentatively identified at the base of the shell-midden (González Morales and Arnaud 1990; Arias et al. 2015). Under the and in the shell-midden layer, several burials were identified, which were concentrated in small groups (Stjerna 2015). A further occupation of Neolithic chronology, separated by a chronological hiatus, 
Fig. 1 Location of the TagusMuge, Sado and Mira shellmiddens in Portugal (left) and shell-middens in the Sado valley (right)

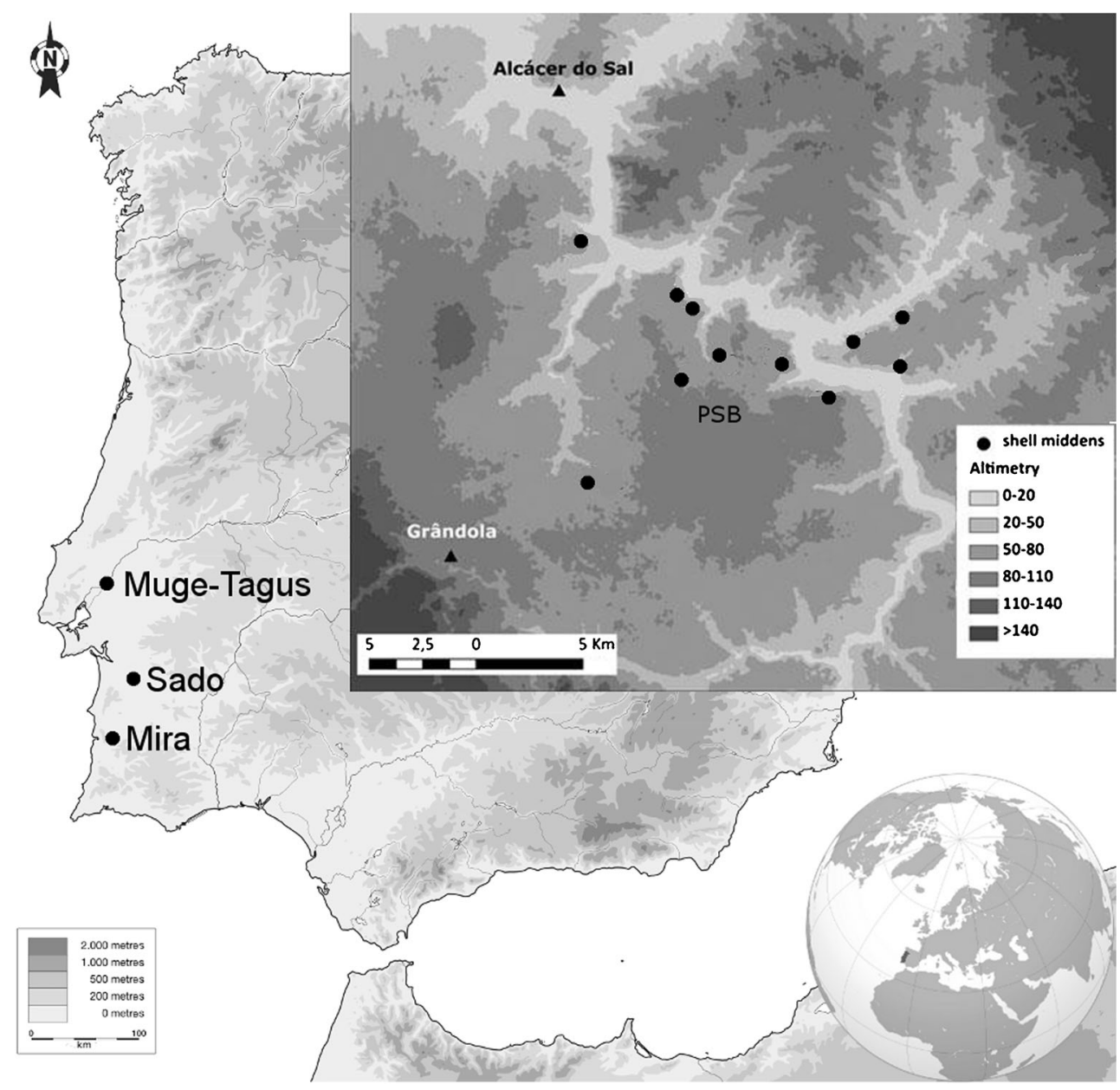

was identified in the upper layers above the shell-midden, with pottery sherds (Diniz and Cubas 2015) and pounding and milling stones.

Radiocarbon dates ascribe the formation of anthropical layers to the sixth and fifth millennia cal BCE (Table 1). Bones from different mammals and non-woody plant macroremains from the Mesolithic layers have been submitted for radiocarbon dating but, due to insufficient carbon or collagen, dating has failed.

\section{Methods}

Although flotation was carried out before our project, only a portion of the layers in the site were sampled and no plant macroremains were recovered (Larsson, pers. comm.). The studied flotation samples were obtained in the most recent excavations between 2010 and 2013 in trench 1 (Fig. 2), which have been excavated extensively $\left(2 \mathrm{~m}^{2}\right.$ in $2010 ; 6 \mathrm{~m}^{2}$ in 2011 of which $4.5 \mathrm{~m}^{2}$ were shell-midden; $12 \mathrm{~m}^{2}$ in 2012 and 2013) and have provided a lengthy and complex stratigraphy. Micromorphological analyses (Simões et al. 2015) complement the stratigraphical description of trench 1 (Araújo, Arias and Diniz 2015; Arias et al. 2016, Fig. 3).
An extensive sampling and retrieval strategy for plant macroremains have been carried out; $100 \%$ of the nonsuperficial soil, excavated from 2010, has been collected in 101 samples and has been floated in a Siraf-type machine (Williams 1973), with a mesh of $250 \mu \mathrm{m}$ for the recovery of the light fraction and a $1 \mathrm{~mm}$ mesh for the heavy fraction. A random subsample (Fig. 3; Table 2) of light flotation fractions, selected by pinch or grab strategy (Lennstrom and Hastorf 1995), has been chosen for this first stage of study and has been sorted with the aid of an optical magnification instrument (a Leica S8 APO stereomicroscope). The heavy fraction of each light fraction flotation sample has been also examined.

\section{Results}

Although not numerically rich, relatively diverse assemblages of plant macroremains have been recovered (Table 3; Fig. 4). A preliminary list of taxa (amended here) was published previously (López-Dóriga, Diniz and Arias 2015). The assemblage has been mostly obtained from light flotation fractions; flotation has been very effective at this particular site, as the heavy fractions have not produced new determinable plant 


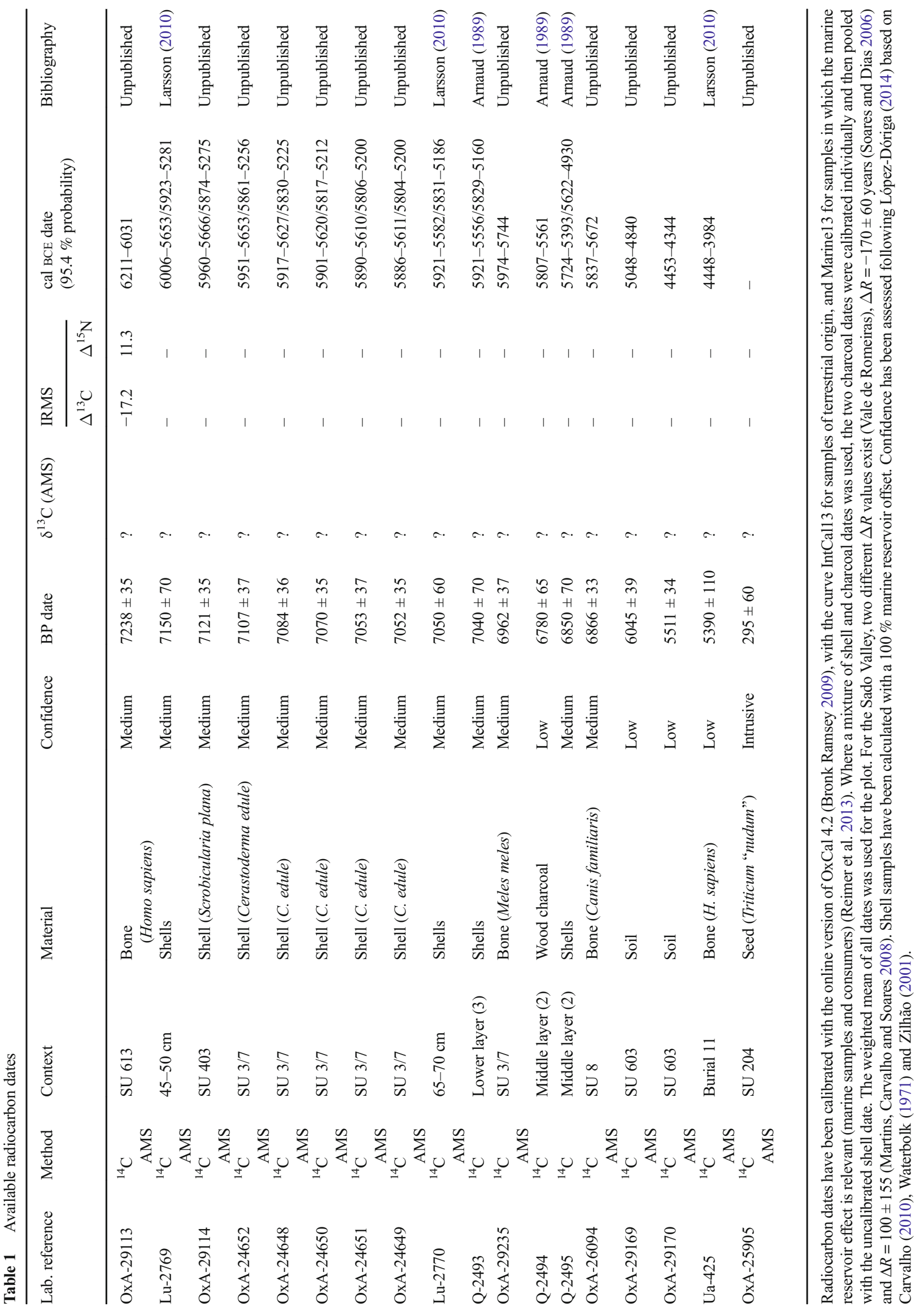




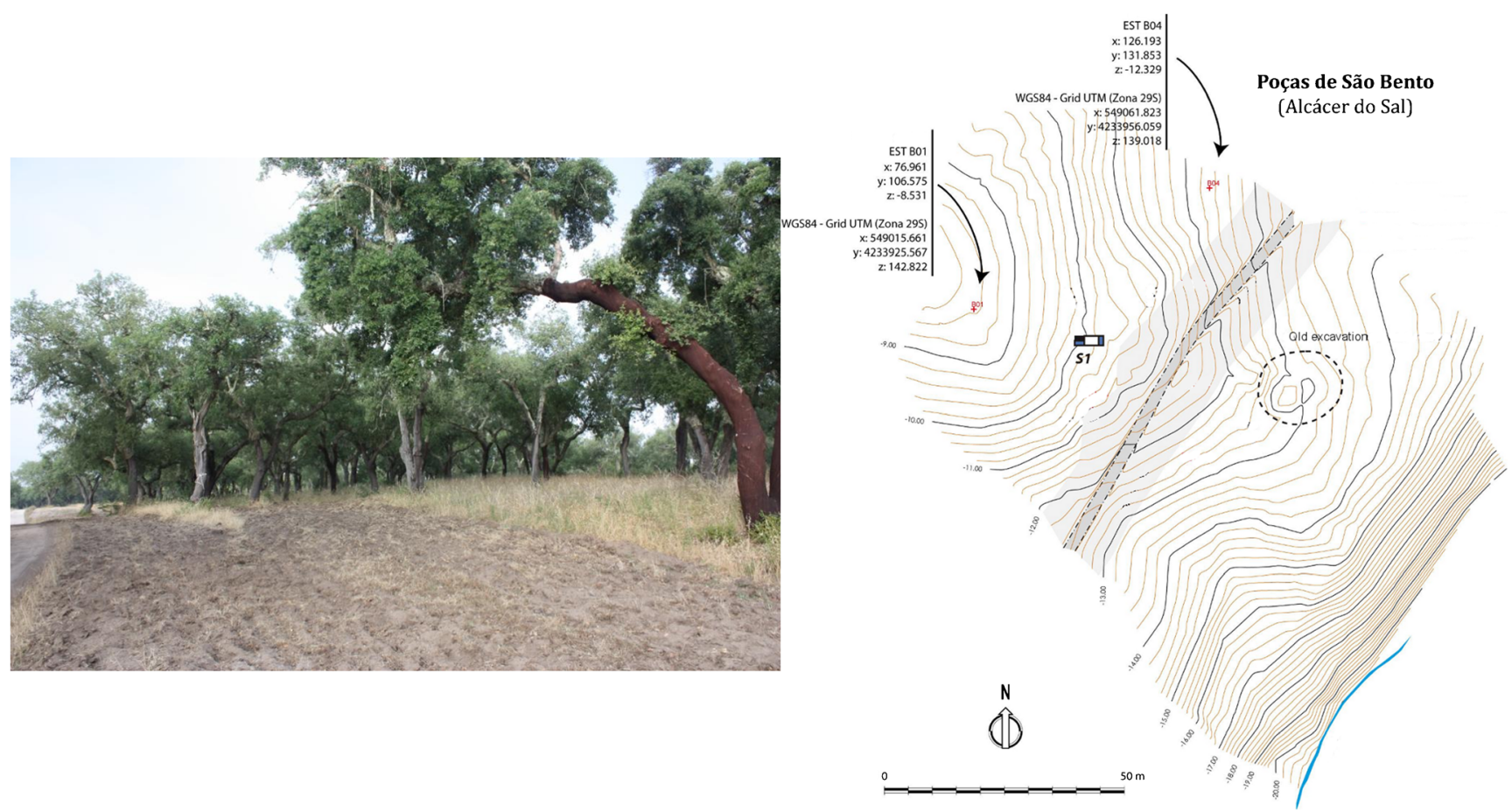

Fig. 2 Left: General view of the central area of Poças de São Bento before the intervention. Photograph by Mariana Diniz. Right: General topography of Poças de São Bento and location of trench 1 (S1) within the Sado-Meso project. Image by Luis Teira

remains. A high number of plant remains has been recovered in such a fragmentary and eroded state of preservation that their taxonomical determination is impossible by macroscopical observation alone. Preservation of the determinable plant macroremains is heterogeneous: whilst very fragmentary and eroded remains are present, some seeds are very well preserved. In fact, bad preservation involves more often erosion than fracture, as the indices of fragmentation are average. Other types of remains that have been recovered within the light flotation fractions were as follows: uncharred seeds, mycorrhizal fungi sclerotia (tp. Cenococcum geophilum), termite and rodent coprolites and insect parts.

\section{Discussion}

\section{Preservation}

It is a well-known fact that preservation by charring, indispensable for the recovery of ancient plant remains in a dry

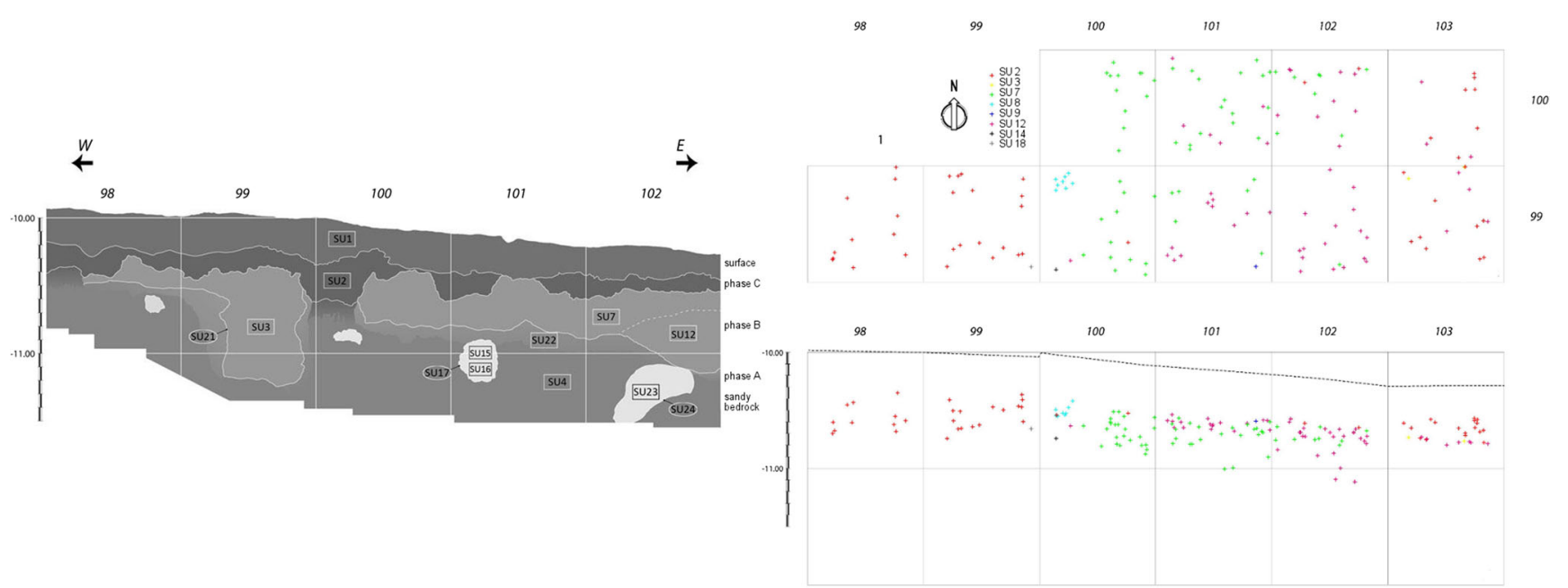

Fig. 3 Left: Profile of the north section in trench 1. Right: Vertical (top) and horizontal (bottom) aleatory distributions of flotation samples by SU from trench 1. Images by Luis Teira 
Table 2 Archaeobotanical sampling strategy developed at Poças de São Bento

Trench 1

\begin{tabular}{|c|c|c|c|c|c|c|}
\hline & \multicolumn{4}{|c|}{ SUs from phase B (first phase) } & \multirow{2}{*}{$\begin{array}{l}\text { Phase C } \\
\text { (second phase) } \\
\text { SUs 2, 9, } 14 \text { and } 18\end{array}$} & \multirow[t]{2}{*}{ Whole sequence } \\
\hline & $3 / 7$ & 8 & 12 & Total & & \\
\hline No. of assessed samples & 237 & 13 & 260 & 510 & 238 & 748 \\
\hline Excavated \% sampled & $100 \%$ & $100 \%$ & $100 \%$ & $100 \%$ & $100 \%$ & $100 \%$ \\
\hline No. of analysed samples & 120 & 13 & 55 & 188 & 68 & 256 \\
\hline$\%$ of analysed samples & $67 \%$ & $100 \%$ & $21 \%$ & $57 \%$ & $29 \%$ & $56 \%$ \\
\hline
\end{tabular}

environment such as this, produces a bias towards certain plants and plant parts (e.g. Zapata Peña 2000). In addition, there are factors which influence the preservation of charred plant remains in a site like this. On the one hand, shellmiddens are far from ideal deposits for the preservation of charred plant macroremains which become easily eroded in soils with a high level of calcium carbonate (Braadbaart, Poole and van Brussel 2009). On the other hand, because of the Mediterranean climate, with its very hot and dry summers, carbonised remains near the surface may have dried out and broken up when exposed to percolating moisture during the wet autumn and winter (Hansen 2001). However, the existence of multiple charring and deposition events being responsible for the assemblage, most likely in tertiary position (Fuller, Stevens and McClatchie 2014), can also explain these heterogeneous states of preservation, particularly when differences are seen at the horizontal distribution.

Plant macroremains have been recovered and distributed through the archaeological stratigraphical units mixed with other archaeological material. The remains are generally small in size, never more than $5 \mathrm{~mm}$ and most often less than $2 \mathrm{~mm}$, a fact which supports the brooming hypothesis (Antolín $\mathrm{i}$ Tutusaus 2010a): very small remains result dispersed upon regular sweeping of functional areas (McKellar hypothesis, Miksicek 1987). This, however, does not seem to match the character of the site as a midden in which occupation floors have not been identified yet. More likely, this small size of the plant macroremains could also be a result of the climate which promotes charcoal cracking (Hansen 2001), which might also account for the sparseness of the determined finds (but not the undetermined) over all the sequence. These types of dispersed distributions have been proven upon radiocarbon dating to be often subjected to intrusive charred materials (Crombé et al. 2013), particularly in palimpsest-like sites where fertile archaeological stratigraphical units are vertically contiguous with one another; this probably accounts for the lack of taxonomical difference between the different stratigraphical units (ancient plant macroremains have probably been displaced throughout the sequence) and the percolation of uncharred modern specimens to the lower units. Because of the dispersed distribution of plant remains, the difficulties in their taphonomical analysis and the potential multiple uses of each plant taxon, the possible functional origins of the plants can be merely hypothesised. Whilst bioturbation by plant roots and burrowing animals probably explains the introduction of modern biological remains (among which are the uncharred seeds, mycorrhizal fungi sclerotia and termite and rodent coprolites) in the archaeological stratigraphical units, which the recent introduction of charred ones is highly improbable. On the one hand, burrowing animals might intentionally transport uncharred seeds for their consumption but not charred ones, unless accidentally. On the other hand, no correlation exists between the uncharred seeds and the charred ones, although some taxa appear in both states of preservation, most uncharred seeds are not preserved in a charred form and vice versa. The existence of natural fires, which could eventually carbonise different plant parts (Scott 2010) and less often seeds (Miksicek 1987), has not been detected in the form of an ash or a charcoal layer in the excavated sequence. In addition, radiocarbon dating of non-woody plant macroremains has been tried in several instances: three remains from the studied area, trench 1 (a Pinus sp. bract scale fragment and two Setaria sp. and Lolium sp. grains) could not be successfully dated due to insufficient carbon; another grain from another excavation area (trench 3), with a taxonomical identification which suggested it was intrusive (Triticum "nudum"), has proved to contain enough carbon and has been dated to a modern chronology. This could not be used as a proof of the age of the charred plant remains, but together with the previous arguments, it supports their presumed ancientness.

As in the case of carbonised seeds, charred termite faecal pellets and fungi sclerotia are quite likely ancient remains. Termite faecal pellets might have been accidentally charred when deadwood was used as fuel or termites themselves might have been cooked for eating. C. geophilum fungi sclerotia are ectomycorrhizal fungi, these are, fungi which thrive in forest soils in symbiosis with different plant roots, mostly from woody species, and among them is pine. Their preservation by charring might be accounted for by two potential explanations: either they were attached to underground plant parts which could have been cooked and, if charred, have not been preserved (tubers 


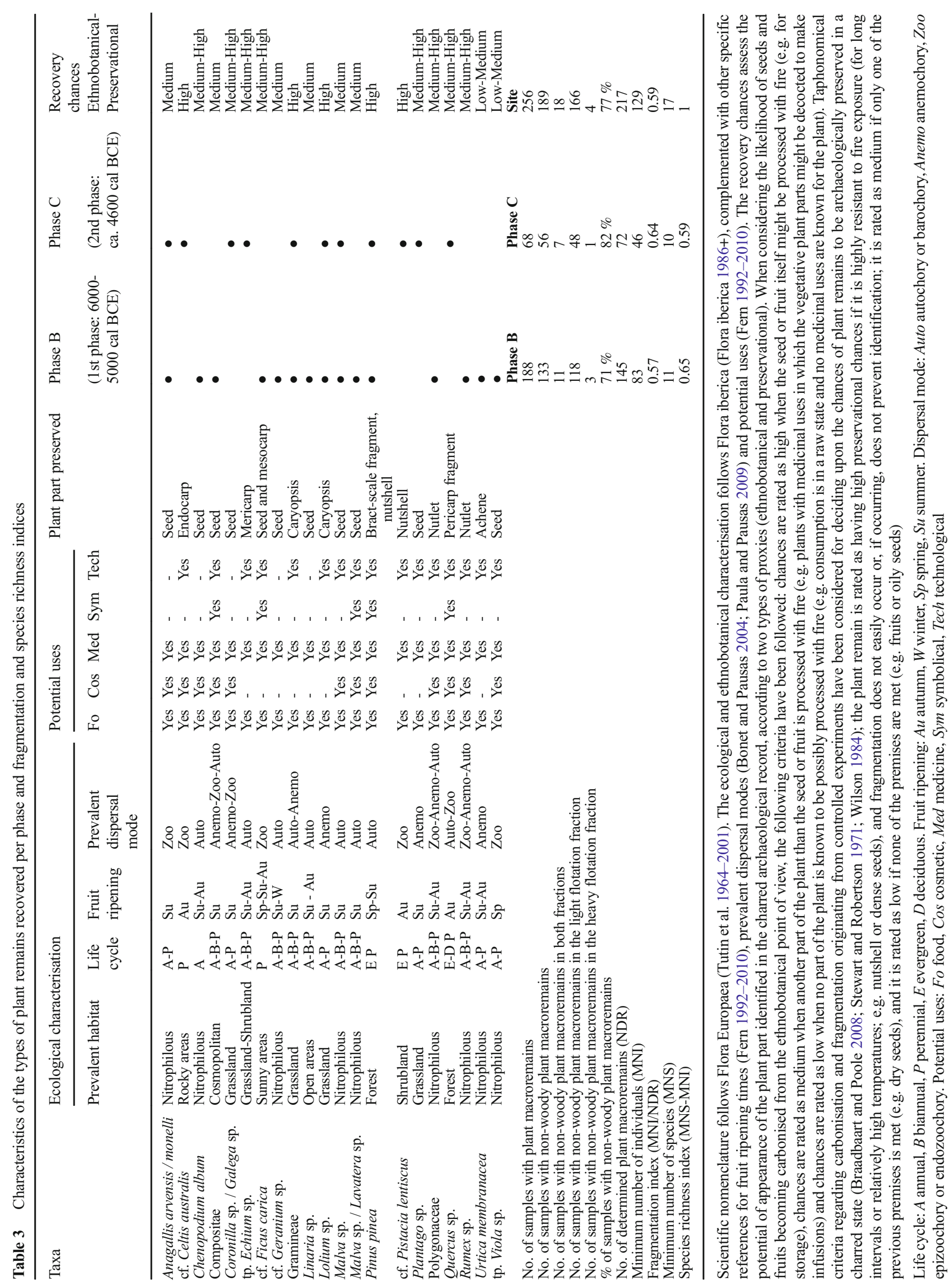


and rhizomes are usually rich in water and are less able to survive charring) or they could have been dispersed in the soil and become accidentally charred by hearths (which might have not been recognisable hearths, Groenendijk 1987).

\section{Function}

It is also a well-known fact that plant remains can enter a site in many different ways (van der Veen 2007), related or unrelated to their actual use. Very few certainties can possibly be established when interpreting the presence of wild plant remains in archaeological sites, although pathways for a better assessment are being developed (Berihuete-Azorín 2016).

The plant macroremain assemblage from Poças de São Bento suggests the potential exploitation of the typical Holocene open Mediterranean pine woodland (van der Schriek et al. 2008). Wild grasses from open grassland areas (Lolium sp., Gramineae) were present in sediments from both occupation periods (phase B and phase C). Evidence for the intensive exploitation of undomesticated small-grained wild grasses in prehistorical times is well known from other regions (e.g. Weiss et al. 2004). However, the dispersal mode for most wild grasses is anemochory (wind transportation), which means that their potential arrival in a hearth in the site by chance cannot be excluded. Spikes and grains could have been gathered in summer by cutting, uprooting, beating or hand plucking (Hillman 1984-1986) and then stored, depending on the intended use of the plant or plant parts. Seeds might have been used for food, whilst the straw could have been left in the fields or could have been employed for different manufactures, such as building, weaving and bedding. (MingoteCalderón 1987). No grass chaff has been recovered surrounding the grains, and two reasons might be behind this phenomenon: chaff was present but did not survive the charring event, as it is less likely than grains to survive (Boardman and Jones 1990), or was destroyed upon deposition or chaff was absent because the grain was already dehusked when charred, such as would happen in the later stages of processing (van der Veen 2007). Grains could have been roasted to help dehusking, for drying and storing or for some sort of culinary preparation. The grains could be stored in aboveground facilities, in which case they could be easily consumed piecemeal as needed, or in underground storage pits, which would allow for a long-term storage period of at least a year.

Other herbaceous plants have a testimonial presence in the site, and their interpretation might be controversial, because the natural ways in which they might have arrived at the site are various, and their potential uses are also diverse. These are plants from grasslands (Anagallis arvensis/monelli, Geranium sp., Linaria sp., Plantago sp.) which would have been ripe by the same time as wild grasses and, if intentionally gathered, could have been prepared for immediate consumption or delayed medicinal use. Even if they were not intentionally gathered, as they are edible, they might have been consumed if accidentally gathered (Hillman, Legge and Rowley-Conwy 1997), as these plants might be eaten as green vegetables and prepared into medicines. These uses would leave few chances for the seeds to be carbonised, so their rarity cannot be used as evidence of their accidental presence. Several nitrophilous habitats (A. arvensis/monelli, Chenopodium album, Geranium sp., Linaria sp., Malva spp., Polygonaceae, Rumex spp., Urtica membranacea, Viola sp.) point to the existence of rich humid soils such as would be found in either the floodplain of the valley or the immediate environment of the site, favoured by the creation of disturbed habitats by human activities such as garbage disposal. Slope-thriving plants, such as Echium sp., Geranium sp. and Plantago sp., might have been gathered on valley slopes. All these plants would fruit between spring and autumn, and their vegetative parts could have been consumed raw as green vegetables or they could have been dried for storage and kept to be used piecemeal for other purposes (medicinal, dyes) (Fern 1992-2010). U. membranacea might have been intentionally exploited for its fibres, which have traditionally been used for textile production (Pinto Carvalho 2005). However, despite being potentially useful, remains of these taxa might be accidentally present in the charred assemblage, either because they were growing near the site or because they could have been present either in dung or stomach contents of other animals which might have been exploited or might have left their droppings near the site (Vaquer and Ruas 2009).

The case of Echium sp. could be different. The leaves of plants in this genus might be eaten as green vegetables, the oils in their seeds used for culinary purposes and the whole plants have a wide series of medicinal applications (Fern 1992-2010); their seeds, however, are not usually transported by the wind or by animals, and therefore, an accidental arrival is more unlikely. Some of the plants present have reproductive dispersals consisting of the distant ejection of the seed from the plant (Geranium sp., but contrary to most wild legumes, not Coronilla sp./Galega sp.), which could account for the accidental presence of the seeds of these taxa in the site, if by chance they had fallen near open-air hearths. Otherwise, they might have been gathered in spring or summer before full maturity, whilst the whole plant might have been eaten as a green vegetable, the oils extracted from the seeds of some legumes have traditionally been exploited (Fern 1992 2010). These plants are also appreciated in folk medicine because of their very diverse pharmaceutical properties.

Fruits from different Mediterranean trees would have been gathered between spring and autumn but could have been stored much longer (Riddervold and Ropeid 1988). The problem with fruits, particularly fleshy ones, is they tend to be dispersed by endozoochory (ingestion by animals). Birds, lizards and other frugivorous animals (specialised or non-specialised) eat whole fruits (Torroba Valmori 2013), of which the meat is digested and the seeds and stones are usually excreted, either within 

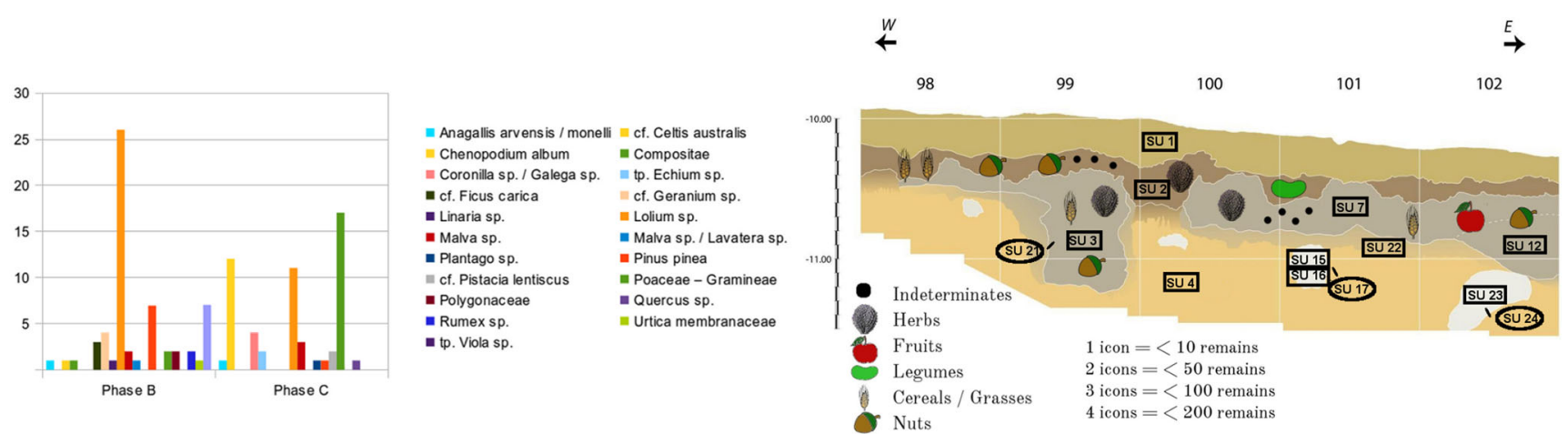

Fig. 4 Left: Abundance of plant taxa (by NMI of seeds or fruits) by phase. Right: Abundance of plant remains per category by SU in section

droppings (in mammals such as foxes, badgers, boars, martens, deers or rabbits) or regurgitated pellets (some birds, such as corvids and gulls) (Debussche and Isenmann 1989). Pinus pinea cones might have been gathered unripe in spring to avoid animal competition for the nuts and could have been opened later in the heat of a hearth (Badal García 2001). Acorns from different oak species (Quercus sp.) would have also been available (van der Schriek et al. 2008), but evidence for their exploitation is scarce; they would also have been gathered in a particular season, autumn, but their storable life might have been prolonged by drying. Figs (Ficus carica) would have been gathered in either spring or summer and autumn, but as they also have excellent storable qualities, they could be the object of delayed consumption or even exchange. $P$. pinea cones might result as charred when exposing them to the fire for opening, to prolong the storable life of the nuts by roasting or for extracting the resin. Cases of owls regurgitating pellets containing pine (Pinus monophylla) shells have been reported (Rhode and Madsen 1998), but this does not seem to occur in the Iberian Peninsula; most of the Pinus remains recovered are cone bract scale fragments and only a few shell fragments: therefore, the non-anthropic contribution of these remains is very unlikely, limited to the possibility of the deciduous cones being buried in the soil on top of which a hearth might have been made. Equally, acorns from oaks (Quercus sp.) might have been gathered and processed with fire for consumption in foodstuffs or beverages, to prolong their storage life or to produce tans or mordants with which to treat leathers and cloths. Figs (F. carica), in turn, might become charred when drying (usually dipped in boiling water and then baked) or be transformed into medicines; however, fig seeds are dispersed by many frugivorous animals which might have been hunted and processed in the site, leaving an opportunity for their stomach contents to be exploited (Buck and Stringer 2014) or discarded. The presence of a fragment of fruit flesh with a seed imprint suggests the former explanation in this case. The case of other fleshy fruits, such as European hackberry (Celtis australis) and lentisc (Pistacia lentiscus), is more difficult to ascertain. Fragments of the endocarp of these taxa, together with others which have not been identified, have been recovered in relative abundance. The fruits might have been brought either intentionally, perhaps eaten and their endocarps discarded into the fire, or accidentally, within the stomach contents of hunted animals, which might or might not have been exploited (Buck and Stringer 2014). The seeds from both taxa, however, are rich in oils which have traditionally been used for culinary purposes (Fern 19922010; Flora iberica 1986+); the extreme fragmentation of the endocarps might have been produced by pressing the uncharred endocarps in order to extract the oils or perhaps is just a postdepositional result (Hansen 2001).

\section{Neolithisation}

The exploitation of plant resources has been revealed in shellmiddens from other world regions (e.g. Mason and Hather 2000; Reddy and Erlandson 2012; Roksandic 2014), but data from the Atlantic coast of the Iberian Peninsula is still scant. In addition, several methodological issues affect the reliability of the interpretation of the importance of those pieces of evidence (Berihuete-Azorín 2016). Although direct data about plant resource exploitation in the Early Neolithic in Portugal is also scarce, limited to two sites in the Estremadura region (López-Dóriga and Simões 2015) at about $150 \mathrm{~km}$ further north-west from the Sado area, some points for general comparison can be brought forwards. The most conspicuous element is the probable intensive exploitation of wild grasses (Lolium sp.) in the Sado, at the same time, in which the Neolithic populations were putting into cultivation (possibly for the first time), the exotic cereals just arrived from the Mediterranean region. The way in which both of these resources has to be processed (gathered, dehusked, ground, etc.) was very similar. The evidence for the exploitation of wild herbaceous plants is very limited in both cases, but they are much less abundant in Early Neolithic sites. On the contrary, the role of wild fruits (both local and non-local in the Early Neolithic) in those sites seems to have been relevant. These elements of comparison might serve as a point of discussion to debate whether these Mesolithic shell-middeners were adopting available local resources to the possibly new 
trend of exploiting grass grains or were continuing their traditions independently from what the coastal farmers were doing, or whether those Early Neolithic populations were locals used to the exploitation of grasses merely who started adopting exotic resources (cereals) to their traditional subsistence patterns, or whether the existence of similarities between the two groups is a result of mere chance and concurrent trends of resource exploitation patterns between human populations and deposition of charred plant remains in archaeological sites. Given the present limited data, it is difficult to tell whether these broad differences and similarities are a result of radically different plant resource exploitation patterns or merely as a result of taphonomy. Hopefully, this data will be complemented with further analyses in the area and other shell-middens in Portugal (e.g. Wollstonecroft et al. 2006) and a better understanding of the role of plant resources in the Mesolithic-Neolithic transition will be achieved.

\section{Conclusion}

This paper proves that charred plant remains might be preserved in shell-middens, despite concerns about the adversity $\mathrm{pH}$ of such environments (Braadbaart and Poole 2008), particularly in open-air sites and Mediterranean climates (Hansen 2001), and despite widespread assumptions on the functional specialisation of shell-midden sites in which other resources than shells are not hoped to be found and (unfortunately, for that very same reason) very frequently not appropriately sampled, contributing to a circular argumentation on the absence of plant remains in shell-middens. This paper shows how the last hunter-gatherers in the shell-middens of the Sado valley in Portugal could have carried out an intensive and diversified exploitation of the wild plant resources available in the environment, with particularly incidence in wild grasses, precluding the adoption of cereals with very similar processing requirements for consumption. However, the functional interpretation of the plant remains recovered is a problematic subject (BerihueteAzorín 2016), due to reasons inherent to the characteristics of tertiary archaeobotanical assemblages in general (Fuller, Stevens and McClatchie 2014) and to characteristics of the plant taxa in particular, which could have arrived to the site from more than one way (Wright 2010). Taphonomy plays a very important role in Neolithisation discussions (e.g. Berger and Guilaine 2009; Zilhão 2011), but it rarely includes solid discussions about the preservation of plant remains and how their analysis can contribute to the understanding of the site formation processes.
Acknowledgments Most of the analytical work carried out for this paper was undertook with $\mathrm{PhD}$ funding from the University of Cantabria for the main author (IL-D). Fieldwork and radiocarbon dating were carried out in the framework of Sado-Meso project, an international collaborative project resultant from several research projects funded by the Spanish Ministry of Science (P.I.: Pablo Arias) "La implantación de las especies domésticas en la Europa atlántica" (DOMATLAN) (HAR2008-06477-C03-00/HIST), subproyecto 1: "La implantación de las especies domésticas en la Europa atlántica: Cronología e impacto en la dieta humana" (DOMATLANTICA) (HAR2008-06477-C03-01/ HIST; "Coastal transitions: A comparative approach to the processes of neolithisation in Atlantic Europe " (COASTTRAN) (HAR2011-29907C03-01/HIST), subproyecto 1: "From shell middens to crop fields: The transition to the Neolithic in the coastal regions of SW Europe"; "Coastal societies in a changing world: A diachronic and comparative approach to the Prehistory of SW Europe from the late Palaeolithic to the Neolithic" (COCHANGE) (HAR2014-51830-P) and the Portuguese Ministry of Education and Science (P.I.: Mariana Diniz) ["Retorno ao Sado: Um caso entre os últimos caçadores-recolectores e a emergência das sociedades agropastoráis no sul de Portugal” (PTDC/HIS-ARQ/121592/2010)].

\section{References}

Álvarez M, Godino IB, Balbo A, Madella M (2011) Shell middens as archives of past environments, human dispersal and specialized resource management. Quat Int 239(1-2):1-7. doi:10.1016/j. quaint.2010.10.025

Álvarez-Fernández E, Arias P, Diniz M, Simões T 2012 Marine resource exploitation during the Mesolithic and the Early Neolithic in Portugal: preliminary data from Poças de São Bento (Alcácer do Sal) and Lapiás das Lameiras (Sintra). Conference delivered at Archaeomalacology Working Group

Antolín i Tutusaus F (2010b) Les propietats del registre paleocarpològic: el punt de partida per a l'estudi de la seva representativitat arqueològica. Cypsela 18:299-306

Antolín i Tutusaus F (2010a) La potencialitat del registre carpòlogic per a l'estudi de la percepció, el treball i el consum de recursos vegetals per part de le societats prehistòriques. Revista d'Arqueología de Ponent 20:197-214

Antolín F, Berihuete M \& López O 2016. Archaeobotany of wild plant use: approaches to the exploitation of wild plant resources in the past and its social implications. Quaternary International 404, part A 1-3. 10.1016/j.quaint.2016.01.029

Araújo A (2015) A few steps backwards ... in search of the origins of the late Mesolithic. In: Bicho N, Cunha E, Detry C, Price TD (eds) Muge 150th: The 150th anniversary of the discovery of the Mesolithic shellmiddens, 1-16. Newcastle upon Tyne: Cambridge Scholars Publishing, Cambridge

Araujo A. 2009. Hunter-gatherer adaptations during the Pleistocene/ Holocene transition in Portugal. In: (ed.), Mesolithic horizons: papers presented at the Seventh International Conference on the Mesolithic in Europe, Belfast 2005, 533-540. Oxford: Oxbow Books

Araújo AC, Arias P \& Diniz M 2015. Lithics in a Mesolithic shell mound: new data from Poças de São Bento (Portugal). In: Bicho, N.; Cunha, E.; Detry, C. \& Price, T. D. (ed.), Muge 150th: the 150th anniversary of the discovery of the Mesolithic shellmiddens,. 1 Newcastle upon Tyne: Cambridge Scholars Publishing

Arias P 2007. Neighbours but diverse: social change in north-west Iberia during the transition from the Mesolithic to the Neolithic (55004000 cal BC). In: Whittle, A. \& Cummings, V. (ed.), Going over: the Mesolithic-Neolithic transition in north-west Europe, 53-71. Proceedings of the British Academy 144 Oxford: University Press 
Arias P, Diniz M, Cubas M, Duarte C, Iriarte E, Salzmann C, Teichner F \& Teira L 2016. Looking for the traces of the last hunter-gatherers: geophysical survey in the Mesolithic shell middens of the Sado valley (Southern Portugal). Quaternary International. doi: 10.1016/ j.quaint.2016.02.016

Arias P, Diniz MT, Araújo AC, Armendariz A \& Teira LC 2015. At the edge of the marshes: new approaches on the Sado valley Mesolithic (southern Portugal). In: Bicho, N.; Cunha, E.; Detry, C. \& Price, T. D. (ed.), Muge 150th: the 150th anniversary of the discovery of the Mesolithic shellmiddens, 301-320. 1 Newcastle upon Tyne: Cambridge Scholars Publishing

Arnaud J (1989) The Mesolithic communities of the Sado Valley, Portugal, in their ecological setting. In: Bonsall C (ed) The Mesolithic in Europe. John Donald, Edinburgh, pp. 614-631

Arnaud J (1985) Mesolithic in Portugal: a report on recent research. Mesolithic Miscellany 6(2):11-15

Arnaud J 1993. O mesolítico e a neolitização: balanço e perspectivas. In: (ed.), O Quaternário em Portugal, Balanço e perspectivas, 173-184. Lisboa: Colibri

Arnaud J, Larsson L (1994) Concheiro das Poças de São Bento. Informação arqueológica 9:130-132

Arnaud JM 1990. Le Substrat mésolithique et le processus de néolithisation dans le sud du Portugal. In: Cahen, D. \& Otte, M. (ed.), Rubané and Cardial: actes du colloque de Liège, novembre 1988,. Etudes et recherches archéologiques de l'Université de Liège 39 Liège

Arnaud JM 2000. Os concheiros mesolíticos do vale do Sado e a exploraçao dos recursos estuarinos (nos tempos pré-históricos e na actualidade). In: (ed.), Actas do encontro sobre arqueologia da Arrábida, 21-43. Lisboa: Instituto Português de Arqueología

Badal García E (2001) La recolección de piñas durante la prehistória en la Cueva de Nerja (Málaga). In: Villaverde V (ed) De Neandertales a Cromañones: El Inicio del Poblamiento Humano en las Tierras Valencianas. Universidad, Valencia, pp. 101-104

Balbo A, Madella M, Godino IB, Álvarez M (2011) Shell midden research: an interdisciplinary agenda for the quaternary and social sciences. Quat Int 239(1-2):147-152. doi:10.1016/j. quaint.2011.03.032

Berger JF, Guilaine J (2009) The 8200 cal BP abrupt environmental change and the Neolithic transition: a Mediterranean perspective. Quat Int 200(1-2):31-49. doi:10.1016/j.quaint.2008.05.013

Berihuete-Azorín M (2016) More than a list of plants: a proposal of systematization of ethnobotanical information for archaeobotanical interpretation. Quat Int 404(Part A):4-15. doi:10.1016/j. quaint.2015.10.114

Boardman S, Jones GEM (1990) Experiments on the effects of charring on cereal plant components. J Archaeol Sci 17:1-11. doi:10.1016 /0305-4403(90)90012-T

Bonet A, Pausas JG (2004) Species richness and cover along a 60-year chronosequence in old-fields of southeastern Spain. Plant Ecol 174: 257

Braadbaart F, Poole I (2008) Morphological, chemical and physical changes during charcoalification of wood and its relevance to archaeological contexts. J Archaeol Sci 35(9):2434-2445. doi:10.1016/j.jas.2008.03.016

Braadbaart F, Poole I, van Brussel AA (2009) Preservation potential of charcoal in alkaline environments: an experimental approach and implications for the archaeological record. J Archaeol Sci 36: 1672-1679. doi:10.1016/j.jas.2009.03.006

Bronk Ramsey C (2009) Bayesian analysis of radiocarbon dates. Radiocarbon 51(1):337-360

Buck LT, Stringer CB (2014) Having the stomach for it: a contribution to Neanderthal diets? Quat Sci Rev 96(0):161-167. doi:10.1016/j. quascirev.2013.09.003

Carvalho AF (2010) Chronology and geography of the MesolithicNeolithic transition in Portugal. In: Armbruester T, Hegewisch M (eds) On pre- and earlier history of Iberia and Central Europe: studies in honour of Philine Kalb. Habelt, Bonn, pp. 45-61

Chandler H, Sykes B \& Zilhão J 2005. Using ancient DNA to examine genetic continuity at the Mesolithic-Neolithic transition in Portugal. In: Arias, P.; Ontañón, R. \& García-Moncó, C. (ed.), Actas del III Congreso del Neolítico en la Península Ibérica, 781-786. Monografías del Instituto Internacional de Investigaciones Prehistóricas de Cantabria 1 Santander

Crombé P, Robinson E, Van Strydonck M, Boudin M (2013) Radiocarbon dating of Mesolithic open-air sites in the coversand area of the North-West European Plain: problems and prospects. Archaeometry 55(3):545-562. doi:10.1111/j.14754754.2012.00693.x

Cruz Berrocal M (2012) The Early Neolithic in the Iberian Peninsula and the Western Mediterranean: a review of the evidence on migration. Journal of World Prehistory 25(3-4):123-156. doi:10.1007/s10963012-9059-9

Dean RM, Valente MJ, Carvalho AF (2012) The Mesolithic/Neolithic transition on the Costa Vicentina, Portugal. Quat Int 264(0):100 108. doi:10.1016/j.quaint.2011.10.024

Debussche M, Isenmann P (1989) Fleshy fruit characters and the choices of bird and mammal seed dispersers in a Mediterranean region. Oikos 56(3):327-338

Diniz M. \& Arias P 2012. O Povoamento Humano Do Paleo-Estuário Do Sado (Portugal): Problemáticas Em Torno Da Ocupação Dos Concheiros Mesolíticos. In: Campar Almeida, A.; Bettencourt, A. M. S.; Moura, D.; Monteiro-Rodrigues, S. \& Alves, M. I. C. (ed.), Environmental changes and human interaction along the Western Atlantic Edge,. Coimbra: Associação Portuguesa para o Estudo do Quaternário; Centro de Investigação Transdisciplinar "Cultura, Espaço e Memória"; Fundação para a Ciência e Tecnologia; Centro de Estudos de Geografia e Ordenamento do Território; Centro de Geologia da Universidade do Porto; Centro de Ciências da Terra da Universidade do Minho

Diniz M, Cubas M 2015. Pots for thought: Neolithic pottery in Sado Mesolithic shell-middens. In: Bicho, N.; Cunha, E.; Detry, C. \& Price, T. D. (ed.), Muge 150th: the 150th anniversary of the discovery of the Mesolithic shellmiddens, 367-381. Newcastle upon Tyne: Cambridge Scholars Publishing

Fern K. 1992-2010. Plants for a future: plant species database, http://www.pfaf.org.

Flora iberica EC. (ed.) 1986. Flora iberica. Plantas vasculares de la Peninsula Ibérica e Islas Baleares. Madrid: Consejo Superior de Investigaciones Científicas (CSIC), Real Jardín Botánico

Fraser R, Bogaard A, Charles M, Jones G, Wallace M, Marinova E, Vaiglova P, Heaton T 2013. Integration of $\delta 13 \mathrm{C}$ and $\delta 15 \mathrm{~N}$ crop values in the reconstruction of palaeodiets of early European farmers. Conference delivered at the 16th conference of the International Work Group For Palaeoethnobotany (IWGP)

Fuller DQ, Stevens CJ, McClatchie M 2014. Routine activities, tertiary refuse and labor organization: social inference from everyday archaeobotany. In: Madella, M. \& Savard, M. (ed.), Ancient plants and people. Contemporary trends in archaeobotany, 174-217. Tucson: University of Arizona Press

Gabriel S, Diniz M, Arias P 2013. Mesolithic fishing in the Sado Valley: evidence for coastal environments exploitation in Poças de São Bento. Conference delivered at Muge 150th anniversary of the discovery of the Mesolithic shellmiddens

González Morales M, Arnaud J 1990. Recent research on the Mesolithic in the Iberian Peninsula: problems and perspectives. In: Vermeersch, P. M. \& Van Peer, P. (ed.), Contributions to the Mesolithic in Europe. Papers presented at the fourth international symposium "The Mesolithic in Europe" (Leuven, 1990).

Groenendijk H (1987) Mesolithic hearth-pits in the Veenkoloniën, Prov Groningen, The Netherlands, defining a specific use of fire in the Mesolithic. Palaeohistoria 29:85-102 
Guiry EJ, Hillier M, Richards MP (2015) Mesolithic dietary heterogeneity on the European Atlantic coastline: stable isotope insights into hunter-gatherer diet and subsistence in the Sado Valley, Portugal. Curr Anthropol 56(3):460-470

Gutiérrez-Zugasti I, Andersen SH, Araújo AC, Dupont C, Milner N, Monge-Soares AM (2011) Shell midden research in Atlantic Europe: state of the art, research problems and perspectives for the future. Quat Int 239(1-2):70-85. doi:10.1016/j.quaint.2011.02.031

Hansen J (2001) Macroscopic plant remains from Mediterranean caves and Rockshelters: avenues of interpretation. Geoarchaeology-An International Journal 16(4):401-432. doi:10.1002/gea.1010

Hillman GC (1984-1986) Traditional husbandry and processing of archaic cereals in recent times: the operations, products and equipment which might feature in Sumerian texts. (II parts). Bulletin on Sumerian agriculture 1:114-151

Hillman GC, Legge AJ, Rowley-Conwy P (1997) On the charred seeds from Epipaleolithic Abu Hureyra: food or fuel? Curr Anthropol 38(4):651. doi:10.1086/204651

Jackes M, Lubell D, Meiklejohn C (1997) On physical anthropological aspects of the Mesolithic-Neolithic transition in the Iberian peninsula. Curr Anthropol 38(5):839-846

Jorge SO (2000) Domesticating the land: the first agricultural communities in Portugal. Journal of Iberian Archaeology 2:43-98

Lalueza Fox C (1996) Physical anthropological aspects of the MesolithicNeolithic transition in the Iberian peninsula. Curr Anthropol 37(4): 689-695

Larsson L (2010) Shells in the sand: Poças de Sao bento-a Mesolithic shell midden by the river Sado, Southern Portugal. In: Armbruester $\mathrm{T}$, Hegewisch M (eds) On pre- and earlier history of Iberia and Central Europe: studies in honour of Philine Kalb. Habelt, Bonn, pp. $29-43$

Larsson L (1996) Late Atlantic settlement in Southern Portugal: results of an excavation of a Mesolithic shell midden by the river Sado. Current Swedish Archaeology 4:123

Lennstrom HA, Hastorf CA (1995) Interpretation in context: sampling and analysis in Paleoethnobotany. Am Antiq 60(4):701-721

López-Dóriga I 2014. ¿Por qué datar carporrestos arqueológicos por radiocarbono?. Nailos 1 167-180

López-Dóriga I, Diniz M, Arias P 2015. New reliminary data on the exploitation of plants in Mesolithic shell middens: the evidence from plant macroremains from the Sado Valley (Poças de S. Bento and Cabeço do Pez). In: Bicho, N.; Cunha, E.; Detry, C. \& Price, T. D. (ed.), Muge 150th: the 150th anniversary of the discovery of the Mesolithic shellmiddens, 347-360. 1 Newcastle upon Tyne: Cambridge Scholars Publishing

López-Dóriga IL, Simões T 2015. Los cultivos del Neolítico Antiguo de Sintra: Lapiás das Lameiras y São Pedro de Canaferrim: resultados preliminares. In: Gonçalves, V. S.; Diniz, M. \& Sousa, A. C. (ed.), $5^{\circ}$ Congresso do Neolítico Peninsular. Actas,. Lisboa

Machado J (1964) Subsídios para a história do Museu Etnológico do Dr. Leite de Vasconcellos. O Arqueólogo Português II(5):51-148

Martins H, Oms F, Pereira L, Pike A, Rowsell K, Zilhão J (2015) Radiocarbon dating the beginning of the Neolithic in Iberia: new results, new problems. J Mediterr Archaeol. doi:10.1558/jmea.v28 i1.27503

Martins J, Carvalho A, Soares A (2008) A calibração das datas de radiocarbono dos esqueletos humanos de Muge. Promontoria 6: 73-94

Mason SLR, Hather JG 2000. Parenchymatous plants remains from Staosnaig. In: Mithen, S. (ed.), Hunter-gatherer landscape archaeology: The Southern Hebrides Mesolithic Project 1988-1998, Cambridge: The McDonald Institute for Archaeological Research

Miksicek CH 1987. Formation processes of the archaeobotanical record. advances in archaeological method and theory 10 211-247

Mingote-Calderón JL 1987. La utilización de la paja de cereales en el mundo rural tradicional. Kalathos 7()
Monteiro PD (2013) Wood charcoal analysis of Mesolithic archaeological contexts from Portugal: state of the art. Arkeogazte 3:51-62

Paula S, Pausas J 2009. BROT: a plant trait database for Mediterranean Basin species, http://www.uv.es/jgpausas/brot.htm.

Pimentel N, Nukushina D, Diniz M, Arias P 2015. Lithic materials in the Sado River's shell middens: geological provenance and impact on site location. In: Bicho, N.; Cunha, E.; Detry, C. \& Price, T. D. (ed.), Muge 150th anniversary of the discovery of the Mesolithic shellmiddens, 321-332. Newcastle upon Tyne: Cambridge Scholars Publishing

Pinto Carvalho AM. 2005. Etnobotánica del Parque Natural de Montesinho. Plantas, tradición y saber popular en un territorio del Nordeste de Portugal. PhD thesis, Universidad Autónoma de Madrid

Reddy SN, Erlandson JM (2012) Macrobotanical food remains from a trans-Holocene sequence at Daisy Cave (CA-SMI-261), San Miguel Island, California. J Archaeol Sci 39(1):33-40. doi:10.1016/j. jas.2011.07.001

Reimer PJ, Bard E, Bayliss A, Beck JW, Blackwell PG, Ramsey CB, Grootes PM, Guilderson TP, Haflidason H, Hajdas I, Hatté C, Heaton TJ, Hoffmann DL, Hogg AG, Hughen KA, Kaiser KF, Kromer B, Manning SW, Niu M, Reimer RW, Richards DA, Scott EM, Southon JR, Staff RA, Turney CSM, van der Plicht J (2013) IntCal13 and Marine13 radiocarbon age calibration curves 0-50, 000 years cal BP. Radiocarbon 55(4):1869-1887. doi:10.2458 /azu js rc.55.16947

Rhode D, Madsen D (1998) Pine nut use in the Early Holocene and beyond: the danger cave archaeobotanical record. J Archaeol Sci 25(12):1199-1210. doi:10.1006/jasc. 1998.0290

Riddervold A, Ropeid A (1988) Food conservation: ethnological studies. Prospect Books, London

Roksandic M (2014) The cultural dynamics of Shell-matrix sites. University of New Mexico Press, Mexico

Santos C, Fregel R, Cabrera VM, Álvarez L, Larruga JM, Ramos A, López MA, Pilar Aluja M, González AM (2014) Mitochondrial DNA and Y-chromosome structure at the Mediterranean and Atlantic Façades of the Iberian Peninsula. Am J Hum Biol 26(2): 130-141. doi:10.1002/ajhb.22497

Scott AC (2010) Charcoal recognition, taphonomy and uses in palaeoenvironmental analysis. Palaeogeogr Palaeoclimatol Palaeoecol 291(1-2):11-39. doi:10.1016/j.palaeo.2009.12.012

Simões CD, Iriarte E, Diniz M, Arias P 2015. High resolution XRF chemostratigraphy of the Poças de São Bento shell midden (Sado estuary, Portugal). In: Bicho, N.; Cunha, E.; Detry, C. \& Price, T. D. (ed.), Muge 150th: the 150th anniversary of the discovery of the Mesolithic shellmiddens, 333-346. 1 Newcastle upon Tyne: Cambridge Scholars Publishing

Soares AMM, Dias JMA (2006) Coastal upwelling and radiocarbonevidence for temporal fluctuations in ocean reservoir effect off Portugal during the Holocene. Radiocarbon 48(1):45-60

Stewart RB, Robertson W (1971) Moisture and seed carbonization. Econ Bot 25:381. doi:10.1007/BF02985204

Stjerna RP 2015. Death in place: rituals in practice. In: von Hackwitz, K. \& Peyroteo Stjerna, R. (ed.), Ancient death ways,. Occasional Papers in Archaeology 59

Tereso JP, Costa C, Almeida NJ, Cabaço N, Cardoso JL, Danielsen R, Davis S, Detry C, Ferreira C, da Fonte L, Gabriel S, Jesus A, Leite J, López-Dóriga I, Mendes PM, Pereira V, Seabra L, Valente MJ, Vaz FC (2015) Grupo de Trabalho de Arqueobotânica e Zooarqueologia, resultados da primeira reunião. Al-Madan Online 19(2):45-48

Torroba Valmori P (2013) Semillas de frutos carnosos del norte ibérico. Guía de identificación. Ediciones Universidad de Valladolid, Valladolid

Tutin TG, Heywood VH, Burges NA, Valentine DH, Walters SM, Webb DA (1964-2001) Flora Europaea http://rbg-web2.rbge.org. uk/FE/fe.html 
Umbelino C, Pérez-Pérez A, Cunha E, Hipólito C, Freitas M, Cabral J (2007) Outros sabores do passado: um novo olhar sobre as comunidades humanas mesolíticas de Muge e do Sado através de análises químicas dos ossos. Promontoria 5:45-90

Vaquer J, Ruas MP 2009. La grotte de l'Abeurador Félines Minervois (Hérault): occupations humaines et environment du Tardiglaciaire à l'Holocène. In: (ed.), De Méditerranée et d'ailleurs... Mélanges offerts à Jean Guilaine, 761. Toulouse: Archives d'Écologie Préhistorique

van der Schriek T, Passmore DG, Mugica FF, Stevenson AC, Boomer I, Rolão J (2008) Holocene palaeoecology and floodplain evolution of the Muge tributary, Lower Tagus Basin, Portugal. Quat Int 189(1): 135-151. doi:10.1016/j.quaint.2007.09.007

van der Veen M (2007) Formation processes of desiccated and carbonized plant remains - the identification of routine practice. J Archaeol Sci 34:968-990. doi:10.1016/j.jas.2006.09.007

Waterbolk HT (1971) Working with radiocarbon dates. Proceedings of the Prehistoric Society $37: 15-33$

Weiss E, Kislev M, Simchoni O, Nadel D (2004) Small-grained wild grasses as staple food at the 23000 -year-old site of Ohalo II, Israel. Econ Bot 58:125-134

Williams D (1973) Flotation at Siraf. Antiquity 47(188):288-292
Wilson DG 1984. The carbonisation of weed seeds and their representation in macrofossil assemblages. In: van Zeist WA \& Casparie WA (ed.), Plants and ancient man, Rotterdam: Balkema

Wollstonecroft MM, Snowdon L, Lee G, Agustin P 2006. Archaeobotanical sampling at Cabeço da Amoreira: preliminary results of the 2003 field season. In: Bicho, N. \& Veríssimo, H. (ed.), Do Epipaleolítico ao calcolítico na Peninsula Ibérica, 55-62. 4 Faro: Centro de Estudos de Património, Universidade do Algarve

Wright PJ (2010) Methodological issues in Paleoethnobotany: a consideration of issues, methods, and cases. In: VanDerwarker AM, Peres TM (eds) Integrating zooarchaeology and paleoethnobotany. Springer, New York, pp. 37-64

Zapata Peña L (2000) La recolección de plantas silvestres en la subsistencia mesolítica y neolítica: datos arqueobotánicos del País Vasco. Complutum 11:157-170

Zilhão J 2011. Time is on my side. In: Hadjikoumis, A.; Robinson, E. \& Viner, S. (ed.), The dynamics of Neolithisation in Europe. Studies in honour of Andrew Sherratt, 46-65. Oxford: Oxbow Books

Zilhão J (2001) Radiocarbon evidence for maritime pioneer colonization at the origins of farming in West Mediterranean Europe. Proc Natl Acad Sci 98(24):14180-14185. doi:10.1073/pnas.241522898 